\title{
EDITORIAL CUARENTA AÑOS DE DIFUSIÓN CIENTÍFICA
}

\author{
FORTY YEARS OF SCIENTIFIC DISSEMINATION
}

\author{
Calogero M. Santoro ${ }^{1,2}$ y Vivien G. Standen ${ }^{1}$
}

La edición del primer número de la revista Philosophical Transactions of the Royal Society en marzo de 1665 dio inicio a la tradición de difundir conocimiento generado por la reflexión, observación y experimentación sobre materias que preocupaban a la sociedad y a la intelectualidad de aquella época. La diferencia que marcó esta Revista, que funciona hasta el presente, fue que, previo a su publicación, los artículos comenzaron a ser revisados por pares de dicha Sociedad. En enero de ese mismo año se inició también, con propósitos similares, la revista Journal des Savants que se discontinuó en 1792 y se reinició en $1816^{1}$ (Vittu 2002). La práctica de Philosophical Transactions se multiplicó y expandió en el siglo XIX y más aún en el siglo XX cuando instituciones ligadas a la generación de conocimiento levantaron revistas de este tipo, transformándose en una misión y necesidad vital.

En Chile, específicamente en el ámbito de la antropología, destaca la publicación en 1880 de un único volumen de la Revista de la Sociedad Arqueolójica de Santiago, a la que le siguió la revista Actes de la Société Scientifique du Chili, editada entre 1891 y 1938 (Etcheverry 1989a). En las Actes se publicaron varios estudios bioantropológicos y arqueológicos (Pardo 1898; Vergara Flores 1894a, b). En 1897 se inauguró la Revista Chilena de Historia Natural, que perdura hasta la actualidad, en cuyos primeros números apareció otro reporte bioantropológico del profesor Vergara Flores (1898a, b). En 1908 Federico Philippi fundó la revista Boletín del Museo de Historia Natural, editado en forma discontinuada hasta el presente, en la que publicaron trabajos de arqueología y etnología que se hicieron más numerosos y frecuentes a partir de la década de los años treinta, con los aportes de Ricardo Latcham y Grete Mostny (ver índice en Etcheverry 1990). En 1910, por iniciativa de Enrique Matta,
The first issue of Philosophical Transactions of the Royal Society, which appeared in March 1665, gave birth to the tradition of disseminating knowledge generated by reflection, observation and experimentation about matters that concerned the society and intelligentsia of that time. The distinctive feature of this journal, which continues to publish to this day, was that its articles were reviewed by peers of the Society before being published. In January of that same year, Journal des Savants, which had similar intentions, had been launched, but was discontinued in 1792 and resumed in 1816 (Vittu 2002). The practice of Philosophical Transactions multiplied and expanded in the nineteenth century and even more so in the twentieth century, when institutions tied to the generation of knowledge began to publish journals of this type, which in itself became a mission and a vital necessity.

In Chile, specifically in the field of anthropology, the publication of the only volume of Revista de la Sociedad Arqueolójica de Santiago in 1880 stands out. This was followed by the journal Actes de la Société Scientifique du Chili, published between 1891 and 1893 (Etcheverry 1989a). In the Actes, several archaeological and bioanthropological studies were published (Pardo 1898; Vergara Flores 1894a, b). In 1897, the journal Revista Chilena de Historia Natural was inaugurated, which still continues to this day. In one of its first issues, another bioanthropological report by professor Vergara Flores was published (1898a, b). In 1908, Federico Philippi founded the journal Boletín del Museo de Historia Natural, which publishes discontinuously to this day. This journal published works in archaeology and ethnology, which grew in number and frequency after 1930, with contributions from Ricardo Latcham and Grete Mostny

\footnotetext{
1 Departamento de Antropología, Universidad de Tarapacá, 18 de Septiembre 2222, Casilla 6-D, Arica, Chile. calogero_santoro@yahoo.com; vstanden@chungara.cl

2 Centro de Investigaciones del Hombre en el Desierto (CIHDE), Avenida General Velásquez 1775, oficina 403, Arica, Chile.
} 
se creó la Revista Chilena de Historia y Geografía (Dannemann 2010), que sirvió de medio para importantes estudios en el campo de la arqueología y la antropología, como los trabajos iniciales de Max Uhle en Chile (Uhle 1913). Por esos años, y como parte de las conmemoraciones del centenario de la República de Chile, se creó en 1912 el Museo de Etnografía y Antropología (Alegría 2007) que entre 1916 a 1924 editó la revista Publicaciones del Museo de Etnología y Antropología de Chile (Gusinde 1917). Allí, Uhle publicó sus primeras reflexiones sobre los Aborígenes de Arica, conocidos hoy día como cultura Chinchorro (Santoro et al. 2010; Uhle 1917). Más tarde la Sociedad Biológica de Concepción, creada en 1927, da inicio a la revista Boletín de la Sociedad Biológica de Concepción, que incluyó estudios bioantropológicos (Álvarez y Espinoza 2001; Etcheverry 1989b; Henkel 1933, 1939; Sandoval y Wilhelm 1945).

Gran parte de estos y otros esfuerzos editoriales iniciales en antropología tuvieron un desarrollo pausado y discontinuado, ligado -en algunos casos- a instituciones locales como la Sociedad Arqueológica de La Serena, fundada en 1944, las que iniciaron en 1945 la Revista Publicaciones de la Sociedad Arqueológica de La Serena, dedicada especialmente a la arqueología de dicha zona. En 1957 se da comienzo a la revista Arqueología Chilena en el seno del Centro de Estudios Antropológicos de la Universidad de Chile (Sandoval 1957) -creado en 1955 a partir de la Sección de Antropología Histórica y Social del Instituto Pedagógico, fundado a su vez en 1953 (Schaedel 1957). En 1963 dicho Centro dio inicio a la revista Antropología, que se editó hasta 1967 y se reinició en 1974 (Cunill 1963; Orellana 1974) y en 1968 dio comienzo al Boletín de Prehistoria de Chile. A partir de 1979 esta revista continuó en el Departamento de Ciencias Antropológicas y Arqueológicas (Orellana 1974). En 1978 dicho Departamento refundió Antropología y Boletín de Prehistoria de Chile en la Revista Chilena de Antropología (Dannemann 1978), que se ha publicado irregularmente hasta el presente.

Este panorama de algunas de las revistas vinculadas al campo de la antropología y arqueología coincide con la trayectoria de varias disciplinas científicas en Chile, que comenzaron a desarrollarse en forma más sostenida y continua después de la Segunda Guerra Mundial (Hidalgo y Martínez 1995). La creación de FONDECYT (Fondo Nacional de Desarrollo Científico y Tecnológico) en 1981 permitió (see the table of contents in Etcheverry 1990). In 1910, the journal Revista Chilena de Historia y Geografía was created at the initiative of Enrique Matta (Dannemann 2010). This journal served as the medium for important studies in archaeology and anthropology, such as the first works by Max Uhle in Chile (Uhle 1913). In 1912, the Museo de Etnografía y Antropología was created as part of the commemoration of the $100^{\text {th }}$ anniversary of the Republic of Chile (Alegría 2007), which released the journal Publicaciones del Museo de Etnología y Antropología de Chile between 1916 and 1924 (Gusinde 1917). In this journal, Uhle published his first reflections on the Aborigine of Arica, known today as the Chinchorro culture (Santoro et al. 2010; Uhle 1917). Some years later, the Sociedad Biológica de Concepción, created in 1927, launched Boletín de la Sociedad Biológica de Concepción, which also included bioanthropological studies (Álvarez y Espinoza 2001; Etcheverry 1989b; Henkel 1933, 1939; Sandoval and Wilhelm 1945).

A large number of these publications and other early publishing efforts in anthropology developed slowly and discontinuously, linked in some cases to local institutions such as the Sociedad Arqueológica of La Serena, founded in 1944, which began to publish the journal Publicaciones de la Sociedad Arqueológica de La Serena in 1945, devoted to the archaeology of that area. In 1957, the journal Arqueología Chilena is launched by the Centro de Estudios Antropológicos of the Universidad de Chile (Sandoval 1957). The latter center was established in 1955 stemming from the Sección de Antropología Histórica y Social of the Instituto Pedagógico, which, in turn, had been founded in 1953 (Schaedel 1957). In 1963, this Center initiated the journal Antropología, which stopped publishing between 1967 and 1974 (Cunill 1963; Orellana 1974). In 1968, the Boletín de Prehistoria de Chile was set up by this Center, which, as of 1979, was taken up by the Departmento de Ciencias Antropológicas y Arqueólogicas (Orellana 1974). In 1978, this Department combined Antropología and Boletín de Prehistoria de Chile into one journal, Revista Chilena de Antropología (Dannemann 1978), which has been published irregularly to this day.

This overview of some of the journals related to anthropology and archaeology coincides with the developmental trajectory of several scientific disciplines in Chile, which experienced a sustained and continuous development after World War II 
dar un salto cualitativo en el ámbito científico y tuvo como efecto lateral el mejoramiento y creación de nuevas revistas científicas que hoy compiten en los sistemas mundiales de indización, con resultados notables en los últimos diez años (Aguirre 2011; Gerding 2005).

En otros países de la América Andina también se levantaron iniciativas similares como el Boletín de la Sociedad Ecuatoriana de Estudios Históricos Americanos fundado por Jacinto Jijón y Caamaño en 1918, en el seno de dicha Sociedad. En este Boletín se publicaron estudios arqueológicos del norte de Chile (Uhle 1919a, b). En 1932 Luis E. Valcárcel inició la Revista del Museo Nacional de Perú (Mujica Bayly et al. 2010), mientras que la Sociedad Argentina de Antropología comenzó la edición de Relaciones en 1937. En Bolivia destaca Kahna, fundada por Carlos Ponce Sanjinés y Jacobo Liberman en 1953, ligada a la Municipalidad de La Paz. Esta Revista se mantuvo por diez años, pero en 1972 Ponce Sanjinés impulsó la edición de la revista Pumapunku que es retomada en 1991 por el Centro de Investigaciones Antropológicas de Tiwanaku (Lémuz 2005).

La creación de la revista Chungara, en 1972, tuvo igualmente como objetivo principal publicar los resultados de investigación de un centro interdisciplinario de estudios antropológicos, que en esa época puso en marcha la Universidad del Norte, en la ciudad de Arica, y que aún se mantiene bajo el alero de la Universidad de Tarapacá (Niemeyer 1983). Desde sus inicios la Revista publicó artículos de autores externos y fue un espacio abierto al debate de distintas posiciones teóricas y metodológicas (Hidalgo 1981). De esta manera se perfiló como un referente para los estudios de historia, antropología, arqueología y bioantropología andina, a partir de la realidad del norte de Chile (Córdova 1988). Paralelamente, los procesos de evaluación y certificación de calidad y originalidad de los artículos publicados en la Revista se hicieron cada vez más rigurosos a partir de 1983 (Hidalgo 1983). A consecuencia de ello Chungara comenzó a ser referenciado en índices y directorios bibliográficos de América y Europa. Destaca entre ellos Scientific Electronic Library Online (SciELO) creado en Brasil en 1997 y adoptado en Chile en 1998. Chungara fue incorporada en el 2001 dado que cumplía con los criterios de selección de calidad editorial convenidos para la plataforma SciELO Chile (http://www.scielo. cl) (Aguirre 2011). Otra red importante es Scopus
(Hidalgo and Martínez 1995). The creation of FONDECYT (Chilean national foundation for science and technology) in 1981 meant a qualitative leap forward in the scientific world and, as a side effect, contributed to the improvement and creation of new scientific journals, which today compete in the global indexing systems with remarkable results over the last ten years (Aguirre 2011; Gerding 2005).

Similar initiatives were launched in other countries of Andean America, such as the journal Boletín de la Sociedad Ecuatoriana de Estudios Históricos Americanos, founded by Jacinto Jijón y Caamaño in 1918 as a member of the Society. This Bulletin published archaeological studies of northern Chile (Uhle 1919a, b). In 1932, Luis E. Valcárcel founded the journal Revista del Museo Nacional in Peru (Mujica Bayly et al. 2010), while the Sociedad Argentina de Antropología launched Relaciones in 1937. In Bolivia, Carlos Ponce Sanjinés and Jacobo Liberman established the journal Kahna, in 1953. This journal was associated with the municipality of La Paz and was published for ten years. In 1972, Ponce Sanjinés pushed for the publication of the journal Pumapunku, which was revived in 1991 by the Centro de Investigaciones Antropológicas de Tiwanaku (Lémuz 2005).

Chungara, created in 1972, aspired to publish the results of research carried out at the interdisciplinary center of anthropological studies, which was established at that time by the Universidad del Norte in the city of Arica and is currently under the auspices of the Universidad de Tarapacá (Niemeyer 1983). Since its inception, this journal has published articles by external authors and has been an open space for debating different theoretical and methodological positions (Hidalgo 1981). Thus, the journal has emerged as a leading benchmark for studies in Andean history, anthropology, archaeology and bioanthropology (Córdova 1988). In addition, the processes of evaluation and certification of quality and originality of the articles published in the journal have become more rigorous since 1983 (Hidalgo 1983). As a consequence, Chungara began to be referenced in indexes and bibliographic directories of America and Europe. Foremost among these is the Scientific Electronic Library Online (SciELO), created in Brazil in 1997 and adopted in Chile in 1998. In 2001, Chungara was incorporated into SciELO because it met the selection criteria of editorial quality for 
de Elsevier donde Chungara también está incluida. Pero, sin dudas, el sistema Web of Knowledge and Science (WoK y WoS respectivamente) es la plataforma que concita el mayor interés y se ha vuelto casi en un imperativo para editores de todo el planeta, que buscan distintos caminos para conseguir esta certificación internacional (Salas 2008).

En este provocador y competitivo escenario académico logramos que Chungara fuera aceptada en las Web of Science en el 2005, lo que trajo consigo un incremento en la cantidad y calidad de los manuscritos sometidos a revisión. Junto con ello subió nuestro índice de rechazo, que en los medios más prestigiosos del mundo puede alcanzar hasta un 90\%, mientras que en Chungara es alrededor de un $30 \%$ anual. No obstante lo anterior, se producen distanciamientos de varios meses adicionales entre el momento de aceptación de un artículo hasta su publicación, lo que afecta a autores y a la imagen de la Revista. Por estas razones, a partir de este año se duplicará la cantidad de números editados anualmente. Anteriormente, se publicaba un volumen con dos números anuales, a lo que se agregaban, algunas veces, números especiales. Pasar de una periodicidad semestral a trimestral significa que a partir de 2012 cada volumen contará con 4 números. Con ello se espera reducir el tiempo desde el ingreso de un manuscrito hasta su impresión, que no deberá exceder los 12 meses. Esto permitirá, también, aumentar la cobertura temática de la Revista dentro de su área de especialización, dar cabida a líneas de investigación emergentes y aumentar su cobertura geográfica. Actualmente, recibimos un flujo importante de resultados de investigación antropológica e histórica desde México hasta el extremo sur de Sudamérica, como así también de España.

Este cambio estructural coincide con los 40 años de edición casi ininterrumpida de Chungara, por lo que este plan de edición es a la vez un acto de celebración y conmemoración y constituye otro paso importante en el desarrollo de la Revista, que ha crecido sistemáticamente desde su fundación, hasta transformarse en un órgano de difusión científica reconocido internacionalmente. Esto implica enfrentar importantes desafíos futuros como la puesta en marcha de una plataforma en línea para manejar todo el proceso editorial de los manuscritos. Con estas innovaciones y la mantención de un riguroso control de la calidad, originalidad, cobertura y actualidad de los artículos se debería incrementar el índice de impacto en la Web of Science. the SciELO platform in Chile (http://www.scielo. cl) (Aguirre 2011). Another important network is Scopus, of Elseviere, where Chungara is also included. Yet undoubtedly, the Web of Knowledge and Web of Science (WoK and WoS, respectively) is the platform of highest interest and is almost an imperative for editors worldwide who strive to obtain this international certification (Salas 2008).

In this provocative and competitive academic environment, Chungara was accepted in the Web of Science in 2005, which brought with it an increase in the quantity and quality of manuscripts submitted for review. Accordingly, our rejection rates also increased. For the world's most prestigious journals, rejection rates could be as high as $90 \%$, while with Chungara it is about $30 \%$ per year. Despite this high rejection rate, there is still a lag of several additional months from the moment an article is accepted until its publication. This delay affects authors and the image of the journal alike. For these reasons, starting this year the issues published every year will double. Previously, we had published one volume annually with two issues, with occasional special issues. Switching from a six-month to a three-month periodicity means that, starting in 2012 each volume will contain four issues. Thus, we expect to reduce the time it takes from the moment a manuscript is submitted until it is printed, which should not exceed twelve months. This will also make it possible to widen the thematic coverage of the journal to include emerging lines of research and to broaden its geographical coverage. Currently, we receive a significant flow of anthropological and historical research results from Mexico down to the extreme south of South America, as well as Spain.

This structural change coincides with the 40 years of almost uninterrupted publication of the Chungara. Consequently, this new publication plan is also an act of celebration and commemoration and constitutes another important step in the development of the Journal, which has grown systematically since it was founded, becoming an internationally recognized vehicle of scientific dissemination. This implies facing important challenges in the future such as the launching of an online platform to handle the entire editorial process of the manuscripts. With these innovations and the maintenance of strict control for quality, originality, coverage and relevance of the articles, 
Finalmente, es importante señalar que la plataforma www.chungara.cl es de libre acceso a todos los artículos publicados desde 1972, en formato PDF, y en SciELO a partir de la edición del año 1988. También está disponible con acceso pagado en JSTOR. El acceso pagado a las versiones digitales de gran parte de las revistas científicas tradicionales es un tema que ha levantado fuerte controversia, en la medida que el conocimiento científico se ha transformado en un lucrativo bien intelectual que se transa en el mercado, aun cuando una parte importante de la inversión inicial para la investigación proviene de una amplia variedad de Estados del mundo (Monbiot 2011). Por esta razón la realización de revistas de acceso libre al conocimiento científico, como Chungara, debería multiplicarse para el beneficio de las nuevas generaciones del planeta (Watson et al. 2010).

En suma, desde finales del siglo XIX se comenzaron a publicar revistas científicas en Chile con contenidos bioantropológicos, como así también arqueológicos y etnográficos. Esta vocación editorial fue en aumento a lo largo del siglo XX, pero varias de esas iniciativas no perduraron, o se mantienen con una periodicidad irregular. En contraste las tres revistas chilenas vinculadas a la antropología, arqueología e historia incluidas en la Web of Science: Magallania (Martinic 2009), Estudios Atacameños (Le Paige 1974; Núñez 1996; Serracino 1974) y Chungara, creadas a fines de los años sesenta o comienzos de los años setenta, provienen de iniciativas intelectuales locales que perduran hasta la actualidad, en universidades regionales del Estado.

En su corta e ininterrumpida historia Chungara ha comprimido lo que las revistas europeas han experimentado por más de dos siglos, lo que le da pie para -manteniendo y mejorando sus estándares de calidad y gestión- arraigarse como un medio de difusión antropológica cada vez más sólido y visible para las Américas. we should see a boost in the rate of impact on the Web of Science.

Finally, it is important to highlight that our website at www.chungara.cl offers free access to all the articles published since 1972, in PDF format. All issues from 1988 onwards are also available on SciELO. They are also available with paid access on JSTOR. Paid access to the online versions of a large number of traditional scientific journals has given rise to strong controversy, as scientific knowledge has become a lucrative commodity traded in the market, despite the fact that an important part of the initial investment for research comes from a wide range of public sources (Monbiot 2011). For this reason, more journals should follow the lead of others who offer free access to scientific knowledge, such as Chungara, for the benefit of future generations on this planet (Watson et al. 2010).

In short, starting in the late nineteenth century, scientific journals containing bioanthropological as well as archaeological and ethnographic studies began to be published in Chile. This editorial vocation increased through the twentieth century, but several of the initiatives did not last or they are only published irregularly. In contrast, the three Chilean journals associated with anthropology, archaeology and history included in the Web of Science, Magallania (Martinic 2009), Estudios Atacameños (Le Paige 1974; Núñez 1996; Serracino 1974) and Chungara, created in the late sixties and early seventies, emerged out of local intellectual initiatives that last to this day in provincial state universities. In its short and uninterrupted history, Chungara has gone through what European journals experienced during a period of two centuries, which is good reason for it to become a more solid and visible journal in the dissemination of results of archaeological studies while maintaining and improving its quality and management standards.

\section{Referencias Citadas}

Aguirre, M. 2011. Las revistas científicas chilenas: evolución, mecanismos para su internacionalización, visibilidad e impacto. En Calidad e Impacto de la Revista Iberoamericana, editado por A.M. Cetto Kramis y J.O. Alonso Gamboa, pp. 285-302. Universidad Nacional Autónoma de México LATINDEX, México.

Alegría, L. 2007. Las colecciones del Museo Histórico Nacional de Chile: ¿"Invención” o "construcción” patrimonial? Anales del Museo de América 15:237-248.
Álvarez, P. y P. Espinoza 2001. Dillman S. Bullock, El Naturalista de la Araucanía. Universidad Austral de Chile, Valdivia.

Bullock, D.S. 1949. Dos cántaros de tipo peruano encontrados en Angol y Carahue. Boletín de la Sociedad de Biología de Concepción 24:15-20.

Córdova, J. 1988. Índice general de la Revista Chungara números 1 al 20, 1971-1988. Chungara 21:79-109. 
Cunill, P. 1963. "Antropología” presentación y perspectivas. Antropología 1:3-4.

Dannemann, M. 1978. Prólogo. Revista Chilena de Antropología 1:3. - - - 2010. Prólogo. Revista Chilena de Historia y Geografia 170:13-15.

Etcheverry, M. 1989a. Carlos E. Porter, la "Société Scientifique du Chili" y las "Actes de la Société Scientifique du Chili". Revista Chilena de Historia Natural 62:129-147.

- - - 1989b. Los índices del Boletín de la Sociedad Biológica de Concepción. Revista Chilena de Historia Natural 62:251-278.

- - - - 1990. Índice de los "Anales" y del "Boletín" (Museo Nacional de Historia Natural). Revista Chilena de Historia Natural 63:211-230.

Gerding, V. 2005. La trayectoria de Bosque 1975-2005 y su proyección. Bosque 26:3-4.

Gusinde, M. 1917. El Museo de Etnología y Antropología. Publicaciones del Museo de Etnología y Antropología de Chile 1:1-18.

Henkel, K.O. 1931-1932. Contribuciones al estudio de la antropología chilena. Boletín de la Sociedad de Biología de Concepción 5 y 6:25-39.

- - - 1933. Contribución al estudio de la antropología chilena II. Sobre cráneos encontrados en el conchal Darwin de Talcahuaco. Revista de la Sociedad de Biología de Concepción 7:45-51.

- - - 1939. Contribuciones al estudio de la antropología chilena IX. Observaciones antropológicas acerca de la Isla de Pascua. Boletín de la Sociedad de Biología de Concepción 13:83-105.

Hidalgo, J. 1981. Presentación. Chungara 7:1-2.

- - - 1983. Presentación. Chungara 11:9-10.

Hidalgo, C. y J. Martínez 1995. La investigación científica en la Universidad de Chile: una mirada contingente. Anales de la Universidad de Chile Sexta Serie:25-38.

Lémuz, C. 2005. Carlos Ponce Sanjinés (1925-2005). Obituario. Nuevos Aportes 2:71-75.

Le Paige, G. 1974. Editorial. Estudios Atacameños 2:4-5.

Martinic, M. 2009. Origen y desarrollo del Instituto de la Patagonia. Una perspectiva de cuarenta años. Magallania 37:5-6.

Monbiot, G. 2011. The lairds of learning. Published in The Guardian 30th August. http://www.monbiot.com/2011/08/29/ the-lairds-of-learning/

Mujica Bayly, S., L. Ramírez León, M. Saldarriaga Feijóo y F. Villegas Torres 2010. Presentación. Revista del Museo Nacional 50:9-10.

Niemeyer, H. 1983. Presentación de la Revista Chungara $\mathrm{N}^{\circ} 10$. Chungara 11:183-185.
Núñez, L. 1996. La misión antropológica de la Universidad Católica del Norte en el desierto chileno. En La Universidad Católica del Norte y el Desarrollo Regional Nortino, editado por J. A. González, pp. 209-245. Universidad Católica del Norte, Antofagasta.

Orellana, M. 1974. Presentación. Antropología Segunda Época 1:1.

Pardo, C. 1898. Armas i utensilios de los indios patagones i fueguinos. Actes de la Société Scientifique du Chili 8:121-127.

Salas, C. 2008. Sugerencias para mejorar la calidad de las revistas científicas chilenas: una aplicación en las ciencias forestales con Bosque. Bosque 29:3-10.

Sandoval, L. 1957. Introducción. Arqueología Chilena 1:V.

Sandoval, L. y O. Wilhelm 1945. Comunicación preliminar sobre antropología serológica de los pascuenses. Boletín de la Sociedad de Biología de Concepción 20:11-15.

Santoro, C.M., V.G. Standen, B.T. Arriaza y F. Rothhammer 2010. El legado de Max Uhle en la arqueología de Arica. En Max Uhle (1856-1944) Evaluaciones de sus Investigaciones y Obras, editado por P. Kaulicke y M. Fischer, pp. 349-357. Fondo Editorial de la Pontificia Universidad Católica del Perú, Lima.

Schaedel, R.P. 1957. Prólogo. Arqueología Chilena:1-3.

Serracino, G. 1974. Editorial. Estudios Atacameños 2:3-4.

Uhle, M. 1913. Los indios atacameños. Revista Chilena de Historia y Geografía 9:105-111.

- - - 1917. Los Aborígenes de Arica. Imprenta Universitaria, Santiago de Chile.

- - - 1919a. Fundamentos étnicos de la región de Arica y Tacna. Boletín de la Sociedad Ecuatoriana de Estudios Históricos Americanos II 2:1-37.

- - - 1919b. La arqueología de Arica y Tacna. Boletín de la Sociedad Ecuatoriana de Estudios Históricos Americanos III:1-48.

Vergara Flores, L. 1894a. Tres cráneos de indíjenas bolivianos. Actes de la Société Scientifique du Chili 4:71-91.

- - - 1894b. Un cráneo de indígena boliviano. Actes de la Société Scientifique du Chili 4:18-34.

- - - 1898a. Dos cráneos antiguos de aimaráes. Revista Chilena de Historia Natural 2:121-125.

- - - 1898b. Dos cráneos antiguos de aimaráes. Revista Chilena de Historia Natural 2:57-60.

Vittu, J.-P. 2002. La formation d'une institution scientifique: le Journal des Savants de 1665 à 1714. Journal des Savants:179-203.

Watson, P., A. Trefethen y E. Vander Meer 2010. e-Science: Past, present and future I. Philosophical Transactions of the Royal Society A 368:3759-3760.

1 http://www.persee.fr/web/revues/home/prescript/revue/jds. 